\title{
Euphemism, Orthophemism, and Dysphemism in the Translation of Sexual Languages
}

\author{
Sulistini Dwi Putranti ${ }^{1}$, M.R. Nababan ${ }^{1}$, Sri Samijati Tarjana ${ }^{1}$ \\ ${ }^{1}$ Sebelas Maret University, Indonesia \\ Email: $\underline{\text { sulistinidp@gmail.com }}$
}

\begin{abstract}
This paper analyses the translation of sexual languages from an English novel into Indonesian. The term euphemism comes with orthophemism and dysphemism which mean sweet talking, straight talking and speaking offensively. While euphemism is used to manipulate taboos, impoliteness and profanity, dysphemism uses harsh language or even taboo words. Orthophemism refers to direct expressions, straightforward speaking neither euphemism nor dysphemism. These three terms are found in the novel, and the purpose of this research is to explain and analyse how those terms are translated into Indonesian. The method applied in this research is descriptive qualitative with the strategy of an embedded case study. The source of data is a novel by Sandra Brown and its translation. The result shows that there are many words, phrases and clauses from SL classified into orthophemism, and dysphemism, and they are softened in TL by using some strategies such as euphemism. The translator also applies self censorship when encountering orthophemism and dysphemism which she considers too vulgar or taboo. It is shown in her choosing generalization, reduction and deletion as the techniques to translate them.
\end{abstract}

Keywords: Euphemism; Orthophemism; Dysphemism; sexual languages; translation techniques; translation quality

\section{INTRODUCTION}

Almost all Sandra Brown's novels have already been translated into Indonesian. Her novels cannot be categorized as erotic fictions, because erotic literature is defined as "works in which sexuality and/or sexual desire have a dominant presence [1] while in romantic fictions sex and sexuality are not the main focus of the story. This type of fiction is not intended to arouse the readers' sexual desire; Van Balgooij explains that sexual arousal doesn't appear to be the sole function of the situations portrayed [2]. The translators play an important role in producing a translation of romantic novels consisting sexual languages so that they do not produce pornography.

Sexual languages are often classified into taboo languages because they include the organ and acts of sex [3]. Some translators often apply self-censorship or in Duda's term 'concealing mechanism', in order not to produce a raunchy text or pornography by using euphemism. It is used to soften down harsh or inoffensive language, but it can also be a double-edged sword because the translation might be inaccurate.

The term euphemism according to Allan and Burridge [3] comes with orthophemism and dysphemism which mean sweet talking, straight talking and 
speaking offensively. Euphemism is usually used to manipulate taboos, impoliteness and profanity so they become acceptable, dysphemism uses harsh language or even taboo words. Orthophemism was coined by Allan and Burridge to refer to direct expressions, straightforward speaking neither euphemism nor dysphemism [5].

Hammad [5]) in his writing titled "Euphemism: Sweet Talking or Deception?" was discusses the use of euphemism in two different senses: sweet talking and deception. Sweet talking is used to replace unpleasant or tabooed objects. According to him, taboo depends on whom, when, where it is used. Unfortunately when the unpleasant words are replaced with the sweet ones the association does not have a permanent sweet talking effect, it may change over time. Deception on the other hand changes horrible things into tolerable ones. They change plain fact by using evasive words. The deceivers have direct access to the information that they want to conceal from the public. This relationship governs deception. It is a deceiver-deceived relationship that exists by concealing horrible thing and showing it as a tolerable one that can be handled and controlled easily.

Another study about euphemism is conducted by Bozena Duda [4] with his writing entitled Euphemisms and Dysphemisms: In Search of a Boundary Line. His study tries to reveal the thin boundary line between euphemism and dysphemism. His findings show that euphemism serves to dignify or express politeness and/or respect. This element cannot be found in dysphemisms which serve to name a taboo object. He also mentions that despite the apparently clear, albeit subtle distinction between euphemism and dysphemism, the role of the context and the intention of the speakers in their choice of expressions are very important.

A study about the translation of eroticism is conducted by Yi-ping Wu in his article titled 'A Study on the English Translation of Eroticism: the Case of Li Ang's Sha Fu. His research investigates the strategies applied by the translators in translating sexual descriptions and obscene languages to avoid indecency or to reduce obcenity. His findings show that the translators tend to mitigate the sexual descriptions and obscene words present in the original, and the representation of eroticism inevitably diminishes the negative connotations of sexual abuse imposed upon women. The rendering has inevitably altered the ideological focalization of sexual oppression and violence encoded in Sha Fu and undermines Li Ang's feminist view on destructive gender relationship. Since softening the sexual descriptions and obscene words has undermined Li Ang's feminist view, Wu thinks that the best strategy to apply is augmentation in maintaining the linguistic equivalent of obscenity and vulgarity found in erotic narrative. Wu does not mention about euphemism or dysphemism, yet his findings show that the strategy applied is mostly euphemism. This finding is a bit surprising since the text translated is from Chinese into English, the ST depicts a lot of vulgar language, indecent sex, and psychosexuality.

Another study about euphemism and dysphemism related to sexual languages is conducted by Eliecer Crespo Fernández in 2008. He analyses the function of conceptual metaphors in euphemistic and dysphemistic use, and his findings show that metaphorical terms and phrases referring to sexual taboos can be insightfully described in terms of Lakoff and Johnson's cognitive view of metaphor.

These four studies show that euphemism is mainly used to tone down or to cover up for obscenity, vulgarity and taboo, while the first and second study mainly discuss euphemism without relating it to translation. This gives the research gap for further investigation, how euphemism can be applied in translation, especially translating 
sexual languages and taboo words. The third study investigates the translation of eroticism of a Chinese novel into English. Although the results show that the translators tend to tone down all obscene and harsh languages, Wu does not explicitly mention the use of euphemism. The findings also intrigue further research to compare if the ST is English translated into another language.

More studies are needed about dysphemism, orthophemism, and euphemism in translating erotic fictions, sexual languages, and taboo words from English into Indonesian. This study will bridge this gap and reveal how Indonesian translators deal with euphemism, orthophemism, dysphemism and sexual languages. In order to get a complete investigation, this study will answer the following statement of problems:

1. Are there any euphemism, orthophemism, and dysphemism in those sexual languages?

2. How does the translator deal with the euphemism, orthophemism, and dysphemism?

3. What is the quality of the translation?

\section{METHODS}

The method used is descriptive qualitative which is aimed to seek answers to some questions and to produce findings which are not predetermined in [8]. The source of data is a novel by Sandra Brown titled Where There is Smoke, published by Grand Central Publishing New York in 1993, and its translation 'Pencarian' translated by Monica Dwi Chresnayani, and published by PT Gramedia Pustaka Utama in 2002. The analysis is based on the investigation of data classified into dysphemism, orthophemism, and euphemism, and the techniques applied by the translator. The analysis is also based on the result of an FGD with three experts in Linguistics to evaluate the translation.

\section{RESULTS}

The findings show that there are 12 data classified as dysphemism. These are mostly found in phrases (10 data) and only 2 data are sentences. The phrases refer to male genitals by using taboo word/s for example 'cock', 'erection', 'fuck', while the sentences are sexual activities. There are 8 data classified as orthophemism which means straight talking, and 10 data are euphemism. The data in orthophemism include sexual parts of the body but not the taboo words, for example the words 'breasts', 'nipples', navel. There are 10 data of euphemism and they also refer to to sexual organs, but the data use softer words such as 'mound', 'his shape', 'the center of her body'. All data are shown in the following table: 
TABLE I. DATA CLASSIFICATION

\begin{tabular}{|c|c|c|c|c|}
\hline $\begin{array}{l}\text { Linguistics } \\
\text { Unit }\end{array}$ & $\mathrm{D} / \mathrm{O} / \mathrm{E}$ & SL & TL & Technique \\
\hline \multirow[t]{17}{*}{ Phrase } & Dysphemism & his erection (019) & - & Deletion \\
\hline & Dysphemism & his cock (032) & $\begin{array}{l}\text { Gairahnya } \\
\text { (his desire) }\end{array}$ & Euphemism \\
\hline & Dysphemism & His cock (042) & $\begin{array}{l}\text { Kelelakian } \\
\text { Key (Key’s } \\
\text { virility) }\end{array}$ & Euphemism \\
\hline & Dysphemism & his erection $(074)$ & $\begin{array}{l}\text { kejantanan } \\
\text { Tanner } \\
\text { (Tanner's } \\
\text { virility) }\end{array}$ & Euphemism \\
\hline & Dysphemism & his cock (137) & - & Deletion \\
\hline & Dysphemism & her pubic hair (126) & - & Deletion \\
\hline & Dysphemism & a blow job (005) & $\begin{array}{l}\text { melayani } \\
\text { hasrat (served } \\
\text { the desire) }\end{array}$ & Generalization \\
\hline & Dysphemism & To fuck (008) & $\begin{array}{l}\text { Tidur dengan } \\
\text { lelaki (sleep } \\
\text { with a man) } \\
\end{array}$ & Euphemism \\
\hline & Dysphemism & $\begin{array}{l}\text { Steamy } \\
\text { masturbation }(080)\end{array}$ & $\begin{array}{l}\text { Bermasturbasi } \\
\text { (to } \\
\text { masturbate) }\end{array}$ & $\begin{array}{l}\text { Transposition, } \\
\text { Reduction }\end{array}$ \\
\hline & Orthophemism & her nipples (003) & $\begin{array}{l}\text { Payudaranya } \\
\text { (her breasts) }\end{array}$ & Generalization \\
\hline & Orthophemism & $\begin{array}{l}\text { The tips of her } \\
\text { breasts }(063)\end{array}$ & $\begin{array}{l}\text { Payudaranya } \\
\text { (her breasts) }\end{array}$ & Generalization \\
\hline & Orthophemism & $\begin{array}{l}\text { The lips of her sex } \\
\text { (122) }\end{array}$ & - & Deletion \\
\hline & Euphemism & her mound (039) & $\begin{array}{l}\text { di antara paha } \\
\text { wanita itu. } \\
\text { (between her } \\
\text { thighs) }\end{array}$ & Euphemism \\
\hline & Euphemism & To her center (079) & ke sana (there) & Generalization \\
\hline & Euphemism & $\begin{array}{l}\text { Between her thighs } \\
\text { (120) }\end{array}$ & $\begin{array}{l}\text { Bagian di } \\
\text { antara kedua } \\
\text { pahanya (a } \\
\text { part between } \\
\text { her thighs) }\end{array}$ & $\begin{array}{l}\text { Established } \\
\text { Equivalent }\end{array}$ \\
\hline & Euphemism & $\begin{array}{l}\text { the juncture of her } \\
\text { thighs (127) }\end{array}$ & - & Deletion \\
\hline & Euphemism & her mound (137) & - & Deletion \\
\hline Sentence & Dysphemism & $\begin{array}{l}\text { She licked him } \\
\text { delicately and } \\
\text { sucked him hard. } \\
(045)\end{array}$ & $\begin{array}{l}\text { Ia menjilat } \\
\text { dan mengisap } \\
\text { (she licked } \\
\text { and sucked) }\end{array}$ & $\begin{array}{l}\text { Variation, } \\
\text { Established } \\
\text { equivalent, } \\
\text { Reduction }\end{array}$ \\
\hline
\end{tabular}


TABLE I, CONT.

\begin{tabular}{|l|l|l|l|l|}
\hline Orthophemism & $\begin{array}{l}\text { He touched her } \\
\text { between the thighs } \\
(052)\end{array}$ & $\begin{array}{l}\text { lelaki itu } \\
\text { menyentuhnya } \\
\text { di antara } \\
\text { kedua } \\
\text { pahanya }(\mathrm{He} \\
\text { touched her } \\
\text { between her } \\
\text { thighs })\end{array}$ & $\begin{array}{l}\text { Established } \\
\text { equivalent }\end{array}$ \\
\hline
\end{tabular}

The analysis of the translation technique is based on Molina and Albier's theory of translation techniques, published in Meta journal titled Translation techniques revisited: A dynamic and functionalist approach [9]. They proposed a revision on Vinay and Dalbernet's translation procedures by differentiating between procedure, strategy and technique, and they revise the procedures by omitting some procedures and adding some others and the result is as follows: Adaptation, Amplification, Borrowing, Calque, Compensation, Description, Discursive creation, Established equivalent, Generalization, Linguistic amplification, Linguistic compression, Literal translation, Modulation, Particularization, Reduction, Substitution, Transposition, Variation.

The result shows that there are three data using the phrase 'his cock' in dysphemism, but the translation for each of the phrase is not the same. The first is softened down by using euphemism into 'gairahnya' which literally means 'his lust'. The second phrase is translated into 'Kelelakian Key' which literally means 'manhood'; while the other one is deleted. This also occurs in the phrase 'his erection' which is considered taboo. The two phrases are translated differently by using deletion and euphemism. The second phrase is translated into 'kejantanan Tanner', which literally means 'manly'. The pronoun is changed into the name of the person to avoid confusion, since there is no difference of personal pronoun between a man and a woman in the Indonesian language. Another datum from dysphemism which is not translated is 'her pubic hair'. This is also classified into dysphemism because 'pubic hair' is considered taboo, especially if it is translated literally into Indonesian.

There are three data classified into dysphemism which refer to sexual activity. The first datum, the phrase 'a blow job' refers to an oral sex, and it is considered to be a taboo phrase. This phrase is translated into Indonesian by using a more general phrase 'melayani hasrat' which literally means 'to fulfill the desire'. The context of the phrase is about a woman who barely graduated high school by giving a blow job to a teacher. The translated phrase has toned down the vulgar words so that the outcome is acceptable in the target language. The second phrase is 'to fuck' which is a taboo word for to have sex. This phrase is translated into 'tidur dengan lelaki' which literally means 'to sleep with a man'. By choosing a more general sense and softer tone, the translator is able to transfer the message of engaging in a sexual activity in the TL without producing an obscenity. The phrase steamy masturbation is classified into a dysphemism, because the word masturbation is already a taboo word and it is combined with the word 'steamy' to suggest a hot sexual act. The phrase is translated into 'bermasturbasi' by using two strategies: transposition and reduction. Transposition is used in changing the noun phrase in SL into a verb in TL, while reduction is applied into the omission of the word 'steamy'. The translator applies deletion technique three times and reduction twice for all the 12 data in dysphemism. 
The data classified into orthophemism mostly refer to women's sexual organs including the words nipples, breasts, and mounds. These words are considered orthophemism because they are direct or straight talking. Those words representing the sexual organs as they are without being vulgar or taboo, or softened. The word 'nipple' and the phrase 'the tips of her breasts' are both translated by using a generalized term 'payudara' which literally means 'breasts'. The translator avoids using a specific word in order to create a more acceptable piece of translation. The phrase 'the lips of her sex' is not translated, it is omitted because it is considered taboo. The translator only applies deletion technique once and reduction once for all the 8 data in orthophemism.

In euphemism part, there are 10 (ten) data classified into it. The phrases refer to male and female sexual organ, but the words and phrases are in vague words, not using direct or even taboo words. They are using indirect terms which include the words 'her mound', 'her center', 'between her thighs', to refer to female's sexual organ, and 'his shape', 'the monstrous organ', 'the bulge in his crotch', and 'it' to refer to male's sexual organ. It is clear that even in the SL the writer also applies euphemism to indicate sexual organs, but she also tries not to be too direct all the time.

The translator applies several techniques in translating these data. The phrase 'her mound' appears twice, it literally means a swell, it is translated into 'di antara paha wanita itu' (between her thighs) by using euphemism technique and the other one is deleted. 'Her mound' itself is a euphemism of a female sexual organ, yet the translator uses a softer tone for its translation. Another datum is 'to her center' which also refers to sexual organ and it is translated by using generalization technique into ' $k e$ sana' which means 'there'.

The phrases 'between her thighs' and 'the juncture between her thighs' are also classified into euphemisms because those phrases are referring to female sexual organ, but they do not convey obscenity. These two phrases are translated into two different techniques; the first is translated by using established equivalent, while the other one is not translated (omitted). The translator applies deletion technique three times and reduction once for all the 10 data in euphemism.

TABLE II TRANSLATION QUALITY SCORE
\begin{tabular}{|r|c|c|}
\hline No & Quality aspect & Score \\
\hline 1 & Accuracy & 3 \\
\hline 2 & Acceptability & 2 \\
\hline 3 & Readability & 1 \\
\hline
\end{tabular}

The use of various techniques in translating dysphemism, orthophemism and euphemism found in the novel will result in the quality of the translation. In 2012, Nababan, Nuraeni, and Sumardiono proposed an instrument to evaluate translation, classified into accuracy, acceptability, and readability. These three aspects are examined by using some qualitative parameters, and given a score for each of the aspect. The highest score is 3 (three), the middle is 2 (two), and the lowest is 1 (one). The accuracy is classified into three; they are accurate (3), less accurate (2), and not accurate (1). The acceptability is also classified into three; they are acceptable (3), less acceptable (2), and not acceptable (1). And readability is classified into three as well; they are high readability (3), moderate readability (2), and low readability (1). The highest score in accuracy is attributed to the perfect transfer of the message in SL to TL, there is no 
distortion in meaning. The translation is considered acceptable when the text sounds natural and sentences are in accordance with the grammar and structure in the Indonesian Language; and the translation is considered readable when the text is easily understood by the readers. Those three aspects then is given score for each of them, as shown in the following table:

The table shows that the accuracy is given the highest score because it is considered the most important aspect in translation. The acceptability ranks the second because a good piece of translation should not sound as a translation, and the last is the readability which is put in the lowest rank. After the translation has been evaluated, the score is calculated to see the overall quality. The range of score is as follows:

TABLE III RANGE OF QUALITY OF TRANSLATION

\begin{tabular}{|l|l|l|c|c|}
\hline Range & Accuracy & Acceptability & Readability & Translation \\
\hline $2.60-3.00$ & Accurate & Acceptable & High & Good \\
\hline $2.00-2.59$ & Less Accurate & Less Acceptable & Moderate & Moderate \\
\hline $0.00-1.99$ & Not Accurate & Not Acceptable & Low & Bad \\
\hline
\end{tabular}

The range describes the score of the quality of translation. Score $2.60-3.00$ means that the translation is accurate, acceptable, has a high readability, and the overall translation is good. If a translation gets score of $2.00-2.59$, it is considered less accurate, less acceptable, has a moderate readability and overall translation is moderate. When the score is $0.00-1.99$ the translation is classified into not accurate, not acceptable, has a low readability, and overall translation is bad. The following table explains the score for the accuracy, acceptability and readability of the sexual languages classified into dysphemism, orthophemism, and euphemism in novel Where There is Smoke by Sandra brown.

TABLE IV THE SCORE FOR TRANSLATION QUALITY

\begin{tabular}{|l|l|l|l|l|l|}
\hline No & Classification & Accuracy & Acceptability & Readability & Overall \\
\hline 1 & Dysphemism & 2.5 & 2.5 & 2.5 & 2.52 \\
\hline 2 & Orthophemism & 2.63 & 2.75 & 2.75 & \\
\hline 3 & Euphemism & 2,3 & 2.4 & 2.4 & \\
\hline 4 & Average & 2.47 & 2.55 & 2.55 & \\
\hline
\end{tabular}

The table shows that the score for the accuracy in all classification is the lowest compared to acceptability and readability. Euphemism has the lowest accuracy compared to dysphemism and orthophemism. This is the result of applying deletion technique in translating sexual languages. Out of 10 data, the translator did not translate 3 data (applying deletion technique), so that the score is 1 . This classification also has one datum with accuracy score of 2 . This is also obvious in the acceptability and readability score, which is only 2.4. This score means that the accuracy of euphemism translation is less accurate, the acceptability is less acceptable and the readability is moderate. In dysphemism, the translator did not translate three data out of 13. This results in the accuracy, acceptability and readability score of 2.5. This score means that the translator did not translate dysphemism data accurate. The translation gets less accurate, less acceptable and moderate readability. Orthophemism gets the highest score among the three classification. Out of 8 data only one datum gets a 1 score and one datum gets 2 score. The translator has translated orthophemism accurately because it 
gets 2.63 , and it is also acceptable and has a high readability (the score is 2.75 for each of them). Since it only has 2.52 of the overall score, the translation quality is considered less accurate, less acceptable, and moderate readability, and the total quality is moderate.

\section{DISCUSSIONS}

The findings show that there are several data which can be classified into dysphemism, orthophemism, and euphemism. The data mostly refer to male and female sexual organs. From the techniques of translation applied, the translator tends to choose some 'safer' techniques such as generalization, modulation, reduction and even deletion. These techniques are applied whenever the context/s allows her to do so, without giving much consideration on the accuracy of the translation. The translator obviously applies a strict self-censorship in order not to produce obscene language, she directly deletes words and/or phrases which use taboo or vulgar language. This is a little bit surprising because she has chosen some words which are actually not too vulgar. For example in translating the word 'cock' (this word appears many times in the novel) in dysphemism, she has translated it into 'kelelakian' (virility), 'kejantanan' (virility), and 'gairah' (lust) which all of them best replace the meaning of 'cock' without creating pornography, it seems there is no reason for the translator for not translating the even strongest words, because she is able to find the closest natural equivalence. The self-censorship is applied whenever she feels that the phrase (or sentences) is too offensive or is considered as cultural untranslatability and deleting it/them is the best strategy.

Those kinds of techniques are also applied in the other classification which results in a low quality of translation. The most surprising thing is the score for euphemism which is the lowest among the three classifications. Data in euphemism are already softened down, so they are not directly stating taboo words. It seems that the translator finds it difficult to find the closest natural equivalence for the phrase 'her mound', which she omits it many times. From the observation, it is obvious that the translator is reluctant to use the same word/phrase several times, she prefers to choose other words/phrases and if she cannot do it, she simply omits it.

The euphemism as a translation technique chosen by the translator has resulted into a good quality of translation. This is proven in dysphemism classification for any data translated by using euphemism, they get a good score. And it is also found in euphemism classification, the data which are translated by using euphemism technique, they get good scores too. The low quality of the translation is resulted from the wrong choice of translation techniques.

\section{CONCLUSION}

From the analyses, it can be concluded that dysphemism, orthophemism and euphemism in a novel are not always difficult to handle. The translator has demonstrated a very good way in handling the offensive and taboo words (in dysphemism) by translating them using euphemism, generalization or modulation and transposition (shifting the focus of the phrase/sentence). These techniques have produced good quality of translation, but they are not considered taboo anymore. 
Applying reduction, omission, or deletion which are based on high self-awareness and implementing self-censorship is not always a wise decision, because it may distort the message conveyed in the souece language. The readers deserve to read a good quality and accurate translation even though they are not able to access the original book.

\section{REFERENCES}

[1] Brulotte, G. \& Phillips, J. ed. 2006. "Encyclopedia of Erotic Literature”. New York: Routledge.

[2] Van Balgooij, Inge. 2011. "I Have Only Words to Play with! Of Shadowy Folds and Trousers Snake: Translating Erotic Fiction". Unpublished Thesis.

[3] Allan, Keith and Kate Burridge. 2006. "Taboo and the Censoring of Language". Cambridge: Cambridge University Press

[4] Duda, Bozana. 2011. "Euphemisms and Dysphemisms: in Search of a Boundary Line". University of Rzeszow. Círculo de Lingüística Aplicada a la Comunicación 45, 3-19

[5] Hammad, Omar Abu. 2007. "Euphemism Sweet Talking or Deception?" Retrieved from https://www.researchgate.net/publication/29753049_Euphemism_Sweet_Talking_or_Deception

[6] Wu, Yi-Ping. 2009. "A Study on the English Translation of Eroticism: The Case of Li Ang's Sha Fu. The Erotic in Context." Garcia-Sanchez et.al. (ed).

[7] Fernández, Eliecer Crespo. 2008. "Sex-Related Euphemism and Dysphemism: An Analysis in Terms of Conceptual Metaphor". ATLANTIS.Journal of the Spanish Association of AngloAmerican Studies.

[8] Mack, Natasha, et.al. 2005. "Qualitative Research Method: A Data Collector's Field Guide. North Carolina: Family Health International".

[9] Molina, L. \& Albir. A.H. (2002). 'Translation techniques revisited: A dynamic and functionalist approach'. Meta, XLVII, 4 pp. 498-512

[10] Nababan, M.R. et al. 2012. "Pengembangan model penilaian kualitas terjemahan". Kajian linguistik dan sastra vol.24. no. 1 pp. 39-57. 